\title{
EVIDENŢIEREA LEGITĂŢILOR DE DECLANŞARE A EPIZOOTIILOR BACULOVIRALE LA H. CUNEA
}

\author{
Stîngaci $A$. \\ Institute of Genetics, Physiology and Plant Protection, 2002, Chisinau, Padurii str.20, \\ e-mail: aurelia.stingaci@gmail.com
}

\begin{abstract}
In the paper there are presented the results of the researches of existing methods of quality control for cultures of insects for rearing is presented. A new express-method of biological material selection for $H$. cunea establishment has been approbated. This method may be suitable for monitoring of natural populations condition in systems of integrated plant protections of diferent agricultural, ornamental and forest crops with intensive anthropogenic loading. The results of the present study revealed the larvicidal potential of baculovirus isolates found in the larvae of H.cunea, local production of biopesticides, which will reduce the final cost of the product and will more accessible to farmer.
\end{abstract}

Key words: Hyphantria cunea, biological product, baculovirus, biodiversity

\section{Introducere}

Zona temperată oferă condiții favorabile producerii unui spectru larg de culturi, o bogată diversitate de insecte sunt trofic atașate de aceste plante, provocând din punct de vedere economic daune considerabile. Pierderile cauzate de insecte variază în funcție de planta cultivată, zona geografică și metodele de management utilizate. Noile cerințe ale pieței mondiale, orientate spre agricultura ecologică necesită menținerea biodiversității, şi crearea agriculturi durabile prin reducerea sau substituirea completă a produselor chimice $[2,3]$. 
O problemă importantă în patologia insectelor o constituie cunoaşterea principiilor, care stau la baza dinamicii îmbolnăvirii populațiilor de dăunători, a caracterului epizootic al agenţilor patogeni ai bolilor insectelor. Recunoaşterea necesităţii aplicării virusurilor entomopatogene şi a insecticidelor baculovirale, elaborate în baza lor, este determinată de originalitatea calitativă a agenților patogeni, printre care specificitatea, iar caracterul epizootic al lor constituie un avantaj principal fată de insecticidele chimice. Manifestarea caracterului epizootic al baculovirusurilor, fiind o determinantă polifactorială, are loc periodic şi este condiţionată de un şir de factori biotici şi abiotici. În scopul utilizării raţionale a acestor pârghii eficiente, este necesară cunoaşterea profundă a mecanismelor şi legităţilor ce determină reglarea densităţii populaţiilor de insecte dăunătoare sub acţiunea baculovirusurilor. Avantajele enumerate mai sus determină, în mare măsură, necesitatea aplicării în condiţiile de producere a preparatelor virale, însă, este necesar de recunoscut că deocamdată volumul de folosire a lor rămâne redus. Una dintre multiplele cauze care determină stagnarea în domeniul aplicării pe larg a insecticidelor virale este lipsa unor cercetări detaliate în ceea ce privește caracterul epizootic al virusurilor entomopatogene. Paralel cu efectul protector al baculovirusurilor este necesar de menţionat şi caracterul biocenotic de reglare a lor. Mecanismele de declanşare şi dezvoltare a epizootiilor cauzate de baculovirusuri în momentul actual rămân cercetate insuficient [1].

Deşi cercetările anterioare în domeniul patologiei insectelor au fost orientate spre cunoaşterea acţiunii microorganismelor şi, în special, a virusurilor asupra ţesuturilor şi celulelor şi a relaţiilor virus-celulă, în ultimii ani, se remarcă orientarea cercetărilor spre problemele legate de raporturile dintre maladii, mediul exterior şi organismul gazdă. Aceste cercetări au drept scop elucidarea unor aspecte în raport cu factorii care determină apariţia infecţiei virale în populaţiile de insete, dependenţa virozelor de condiţiile de mediu, conservarea şi menţinerea în stare activă a virusururilor în afara organismului insectelor, căile de transmitere a virusurilor, starea de latenţă a virusurilor etc. Dintre factorii de mediu care au influenţă directă asupra maladiilor virale rolul cel mai important se atribuie factorilor climatici, alimentari şi densităţii populaţiilor insectelor-gazdă [4].

Este necesar de a depune efort continuu a soluționa cererea mediului de afacere și a economiei naționale în preparate ecologice de control al insectelor dăunătoare. Controlul biologic reprezintă una din abordările de succes în gestionarea durabilă a insectelor dăunătoare. Toate aceste aspecte, situații şi probleme nesoluţionate, luate în ansamblu, au dictat alegerea temei

\section{Materiale și metode}

Efectivul iniţial de adulţi a fost obţinut din larve colectate în luna iunie a anilor 20072018, din zona municipiului Chişinău şi creşterea lor în condiţii de laborator pe hrană naturală (frunze de arţar).

Selecţia de imago, folosiţi în experienţele ulterioare a fost realizată pe baza diferitor indicatori morfofiziologici, în primul rând, dimensiunea şi aspectul general al larvelor. În vederea elucidării acestor aspecte au fost evaluate dimensiunile adulţilor obţinuţi din larve crescute pe hrană naturală Acer negundo, cu cea a adulţilor obţinuţi din larve hrănite cu mediu artificial, precum şi apariţia diferitor abateri morfometrice în ambele variante. Lungimea corpului şi anvergura aripilor au fost măsurate după moartea adulţilor. Prolificitatea şi fertilitatea femelelor crescute în condiţii controlate au fost determinate în conformitate cu metodologia cercetărilor entomologice,S-a experimentat biopreparatul Virin-ABB-3 realizat de către IGFPP. Determinarea larvelor bolnave s-au efectuat după simptoamele respective, apoi cu ajutorul microscopului. Infectarea larvelor s-au efectuat cu suspensii virale cu titrul de 
$10{ }^{6}$ SPVC la un individ. Observaţiile s-au efectuat începând cu ziua a treia după infecţie. Eficienţa preparatului viral s-a determinat după formula Abbot, care prevede mortalitatea naturală a insectelor $[8,1]$.Datele estimate au fost procesate în conformitate cu pachetul Software Microsoft.

\section{Rezultate și discuții}

S-a demonstrat, că în componența preparatului viral este necesar s-ă se conțină circa $10^{9}$ poliedre. Aceasta a contribuit la obținerea preparatului baculoviral. Rezultatele prezentate în figura 3.5 demonstrează, că larvele sunt cu atât mai sensibile la infecţie, cu cât stadiul expus este mai mic. Dacă larvele sunt infestate la vârste mici se înregistrează $(97,3 \%$ la prima vârstă şi 94,1\% la vârsta a doua) (Figura 1).

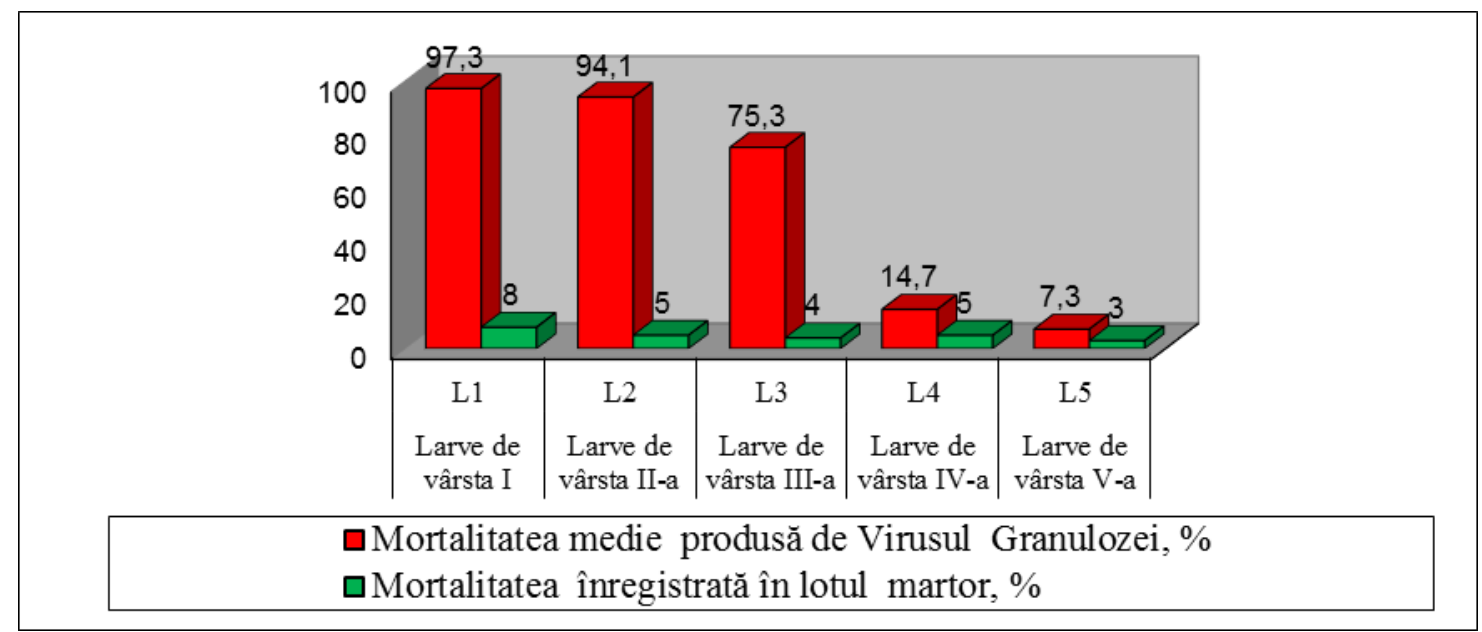

Fig. 1. Susceptibilitatea larvelor de $H$. cunea de diferite vârste la infecţia cu virusul granulozei în experienţă și martor

La vârsta a cincea mortalitatea este foarte redusă $(7,3 \%)$, apropiată de valoarea mortalitatii înregistrate în cazul larvelor din varianta martor. Astfel s-a constatat, că mortalitatea la larvele de vârstă mai avansate este foarte redusă, apropiată de cea a larvelor din varianta martor Acest aspect, are o importantă deosebită când se pune problema utilizării virusului în limitarea densității populațiilor de insecte dăunătoare.

O problemă importantă în patologia insectelor o constituie cunoașterea principiilor, care stau la baza dinamicii îmbolnăvirii populațiilor, a caracterului epizootic al agențiilor patogeni ai bolilor insectelor (Figura 2.).

Una dintre multiplele cauze care determină stagnarea în domeniul aplicării pe larg a baculovirusirilor este lipsa unor cercetări detaliate în ceea ce privește caracterul epizootic al virusurilor entomopatogene, Baculovirusurile pot supraviețui numai, dacă acestea sunt protejate de radiația ultravioletă. Astfel, transmiterea pe orizontală din această nișă ecologică, ar putea fi principala cale de transmitere a infecției. Transmiterea pe orizontală este strâns legată de densitatea populației şi nivelurile de infecție, deși acest lucru poate fi modificat de particularitățile comportamentului insectelor. Prezența unor astfel de gradații din cauza agentului patogen se bazează în primul rând pe transmiterea orizontală şi persistența virusului [7]. 


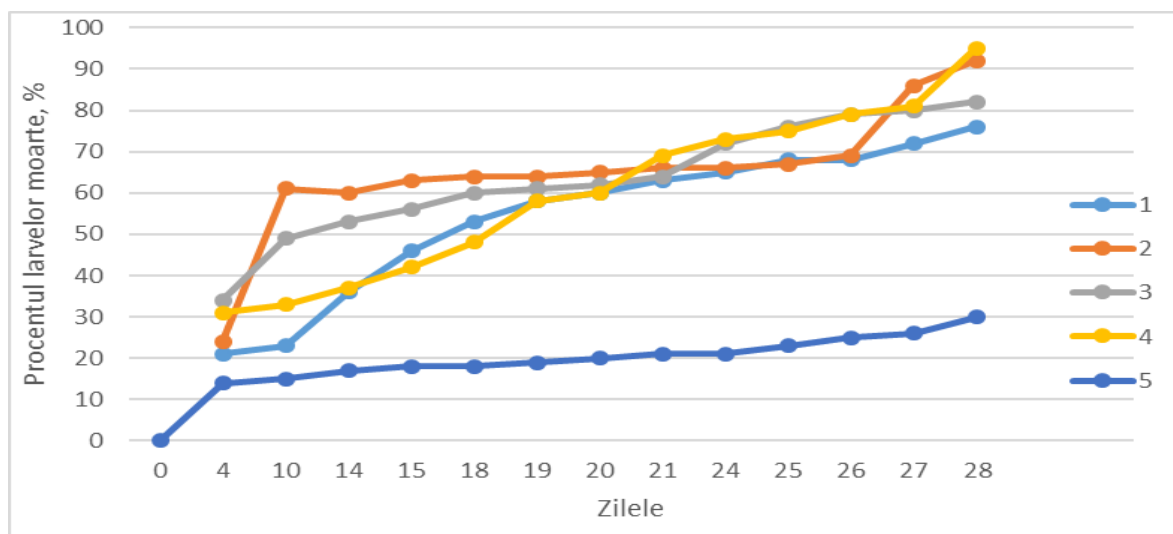

Fig. 2. Dinamica mortalităţii larvelor infectate cu VG în funcție de modelele de transmitere a patogenului: 1 -varianta 1, modul complex de transmitere a infecției: larve infestate și neinfestate au fost ținute și hrănite împreună; 2 - varianta 2, transmiterea infecției prin cale aeriană: larvele neinfestate s-au păstrat în apropiere, dar fără contact cu larvele infestate; 3 - varianta 3, calea orală de infecție: larvele neinfectate hrănite pe frunze pe care se aflau anterior larve infestate; 4 - martor "+": larve infestate cu virus; 5 - martor "-": larve neinfestate cu virus

Deosebit de importantă este modelarea căilor de transmitere pe orizontală a infecției virale în populația $H$. cunea, fiind investigate pentru prima dată trei modele posibile de transmitere a virusului de la larvele infectate la cele neinfestate: 1) Larvele infestate şi neinfestate au fost ținute şi hrănite împreună, asigurând astfel modul complex de transmitere a infecției - prin contact, oral şi pe cale aerogenă. 2) Larvele infestate şi neinfestate se aflau în nemijlocita apropiere, dar nu se hrăneau împreună, evitând posibilitatea transmiterii infecției prin căile respiratorii. 3) Larvele neinfestate au fost hrănite cu frunzele pe care anterior au fost aflate larvele infestate, accentul fiind pus pe transmiterea orală. Acest lucru denotă faptul, că transmiterea pe orizontală într-o singură generație poate evolua, iar aplicarea unei strategii concrete de transmitere este importantă pentru gestionarea epizootiilor, precum şi pentru utilizarea ca agenți de combatere a dăunătorului. Transmiterea pe orizontală evoluează în funcție de condițiile de mediu şi de persistența dăunătorului.

\section{Concluzii}

Necesitatea elaborării metodelor eficiente de identificare a baculovirusurilor este determinată atât de problemele ce țin de controlul calității preparatelor virale, cât şi de tendințele aprofundării cunoștințelor şi aplicării lor în agricultură ecologică. În acest context este foarte actuală problema elaborării unor mijloace principiale noi de a integra un baculovirus apărut în mod natural într-o populație de insecte dăunătoare, într-un biopreparat stabil, sigur şi eficient în controlul speciei. Aplicarea diferențiată a măsurilor de combatere integrată în funcție de faza gradației dăunătorului $H$. cunea, prin utilizarea complexelor (schemelor) cu caracter preventiv în focarele incipiente de înmulțire cu caracter respectiv în focarele în erupție și criză. Din punct de vedere economic sunt rentabile deoarece pot declanșa epizootii virale, care se mențin timp de mai mulți ani. Baculovirușii prezintă un interes științific şi practic în calitate de mijloace de protecție efective şi ecologic inofensive a insectelor. 


\section{Bibliografie}

1. Voloşciuc, L.T. Probleme ecologice în agricultură. Chişinău: Bons Offices, 2009. 264 p. ISBN 978-9975-9774-5-6.

2. Airenne K.J. et al. In vivo application and tracking of baculovirus. In: Current Gene Therapy, 2010, vol. 10, p. 1-8.

3. Dwijenda S. Advances in Plant Biopesticides. In: Springer, India, 2014. 407 p

4. Agrow Biopesticides. Biologicals 2018, an analisis of corporate, product and rfegulatory news. Agribusiness Intelligence, [online]. Informa UK Ltd., Christchurch Court, London EC1A 7AZ, UK, 2018 [citat 21.01.2019]. ISNN 0268-313X. Disponibil: http://www.agrow.com.

5. Biopesticides Market by Active Ingredient (Microbials \& Biorationals), by Types (Bioinsecticides, Biofungicides, Bionematicides \& Bioherbicides), by Application, by Formulation, by Crop Type \& by Geography - Global trends \& forecasts to 2019. In: Markets and Markets Inc., 2015 [citat 21.08.2018]. Disponibil: http://www.marketreportshub.com.

6.

Marrone, P.G. The market and potential for biopesticides. In Biopesticides: State of the Art and Future Opportunities; Gross, A.D., Coats, J.R., Duke, S.O., Seiber, J.N., Eds.; American Chemical Society: Washington, DC, USA, 2014, p. 245258.

7. Theilmann, D.A., Blissard, G.W. Baculoviruses: molecular biology of nucleopolyhedroviruses. In: Encyclopedia of Virology, 3rd edn, Oxford, Academic Press, 2008, pp. 254-265. ISBN 13: 978-0123739353.

8. Чухрий, М.Г. Биология бакуловирусов и вирусов цитоплазматического полиедроза. Кишинёв: Штиинца, 1988. 237 с. 